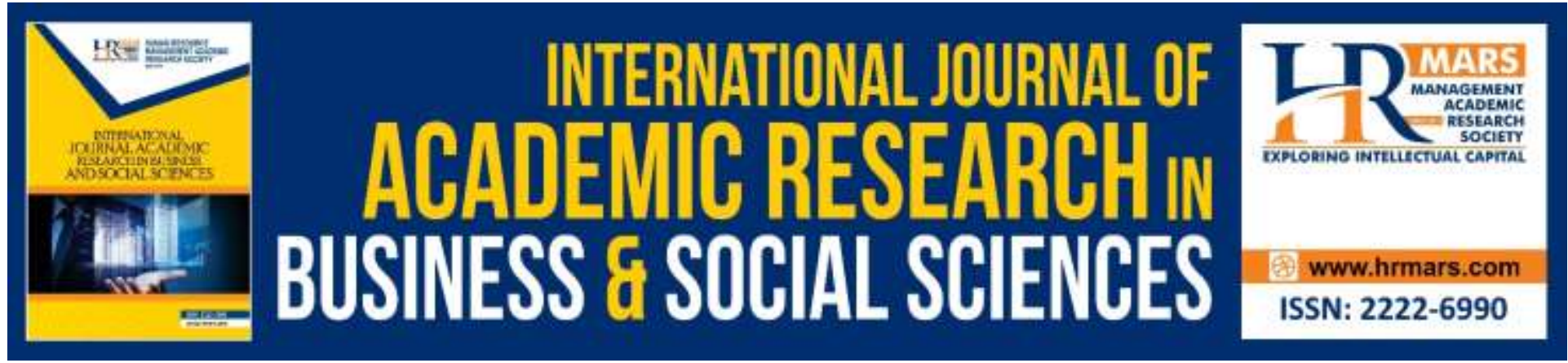

\title{
The Impact of Social Capital and Entrepreneurship on Economic Growth: A Panel Data Approach
}

\section{Chiraz FEKI}

To Link this Article: http://dx.doi.org/10.6007/IJARBSS/v9-i9/6298

DOI: $10.6007 /$ IJARBSS/v9-i9/6298

Received: 02 July 2019, Revised: 10 August 2019, Accepted: 30 August 2019

Published Online: 23 September 2019

In-Text Citation: (FEKI, 2019)

To Cite this Article: FEKI, C. (2019). The Impact of Social Capital and Entrepreneurship on Economic Growth: A Panel Data Approach. International Journal of Academic Research in Business and Social Sciences, 9(9), 320333.

\section{Copyright: (C) 2019 The Author(s)}

Published by Human Resource Management Academic Research Society (www.hrmars.com)

This article is published under the Creative Commons Attribution (CC BY 4.0) license. Anyone may reproduce, distribute, translate and create derivative works of this article (for both commercial and non-commercial purposes), subject to full attribution to the original publication and authors. The full terms of this license may be seen at: http://creativecommons.org/licences/by/4.0/legalcode

\section{Vol. 9, No. 9, 2019, Pg. 320 - 333}

Full Terms \& Conditions of access and use can be found at http://hrmars.com/index.php/pages/detail/publication-ethics 


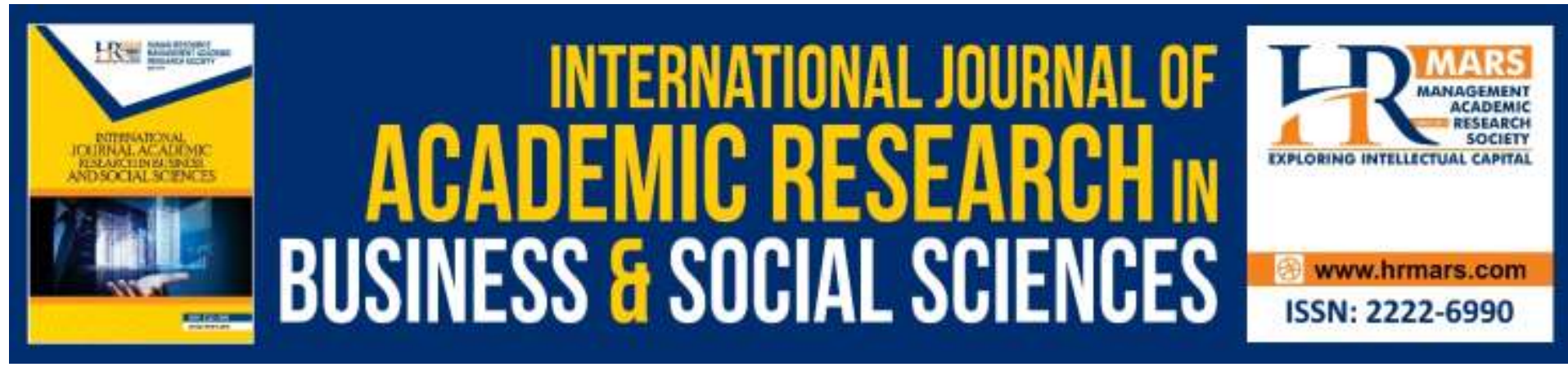

\title{
The Impact of Social Capital and Entrepreneurship on Economic Growth: A Panel Data Approach
}

\author{
Chiraz FEKI \\ Department of Economics, Faculty of Economics and Management of Sfax \\ Email: fekichiraz@yahoo.fr
}

\begin{abstract}
This paper examines the relationship between social capital, entrepreneurship and economic growth. The empirical analysis is performed via the panel data approach to a sample of 40 developed and developing countries from 1990 to 2004 . Our results demonstrate that social capital and economic growth are significantly and positively correlated. The study show that social capital can also have indirect effects on economic growth through other variables, specifically, entrepreneurial activity.

Keywords: Social Capital, Entrepreneurship, Economic Growth, Panel Data.
\end{abstract}

\section{Introduction}

Economic growth is the process by which the national real output of goods and services increases steadily over time. Since Smith (1776), the question of the growth of economies is one of the central concerns of economic research. During its development, the growth theory has focused on variables, such as labor, capital and technical progress, and how factors are combined together to explain the differences in growth between countries. To explain these differences in growth, economic studies have addressed deep determinants, such as the quality of institutions, social capital and entrepreneurship in order to complete the conceptual design of growth.

The interest in the study of entrepreneurship gained momentum in the 70s, through economic theory allowing both empirical results and theoretical reflections. Many developed countries, especially in Europe, had put in place new strategies following years of economic slowdown and falling business creation. Theoretical reflections that have marked the global economy have been reflected in national economies. These changes have shown that economic growth has been sustained not only by economies of scale or scope, but also by firms that play an important role in economic growth.

Thus, an important factor in the success or failure of a new business creation process, which helps the entrepreneur to overcome these difficulties, is this ability to develop and mobilize its social capital, which refers to the networks of relationships of individual or collective agent and the resources he can mobilize through these networks. This allows the contractor to obtain resources that otherwise would not be accessible to him, but a more expensive way in 
terms of time, cost or effort to acquire them. Thus, social capital provides entrepreneurs with two direct benefits: resources and information. The presence of a group of people should be interested in taking risks on their funds to create new business has a positive effect on entrepreneurial activity, and hence on economic growth.

Studies on social capital carried out so far in the field of entrepreneurship, have shown its importance for project creation in companies. In general, the importance of social capital in the field of entrepreneurship is that it provides and allows access to resources or emotional support. In this respect, its relevance is due to the fact that entrepreneurship is linked to innovation and competitive advantage. Indeed, a positive relationship between social capital and entrepreneurship is expected, and indirectly, stimulates economic growth.

In general, in the empirical analysis, there is a positive and significant correlation between social capital and economic growth, but without persisting on the different transmission channels. In addition to the direct effect that social capital can have on economic growth, social structure may also have indirect effects through other variables that can affect economic growth. In the literature related to this subject, the share capital measured by the level of confidence in the economy is a key factor in investment activity, human capital, institutional quality, financial development and entrepreneurial activity.

The purpose of this article is to analyze the direct effects of social capital on economic growth, and to show that a high level of social capital also has an indirect effect on economic growth through its effect on entrepreneurial activity. Finally, this paper is organized as follows: In a first section, we present the concept of social capital. In the second section, we explain the concept of entrepreneurship. In a third section, we clarify the relationship between social capital, entrepreneurship and economic growth. Finally, the fourth section contains suggestions about our own empirical validation.

\section{Literature Review}

\section{The Concept of Social Capital}

Social capital refers to Hanifan (1916) who revealed the importance of community participation in improving school performance. Hanifan defines social capital as "those tangible substances that count most in the daily lives of people, like, the good will, fellowship, sympathy, and social relations between individuals and families who make up a social unit" [Hanifan 1916]. Later, Banfield (1958) used the concept of social capital to reflect the economic decline of southern Italy. Other studies have used this term, sometimes with variations in meaning (Homans, 1961; Jacobs, 1971 and Loury, 1977 to suggest that the mobilization of social relations and cooperation can help individuals improve their welfare.

Though, the popularization of the concept in recent years is due to Bourdieu $(1980,1986)$; he also used the concept of social capital to refer to certain types of resources resulting from the membership of associations, communities and social networks. Bourdieu was the first to give a precise definition of the concept: "Social capital is all actual or potential resources which are linked to possession of a durable network of relationships more or less institutionalized, or, in other words, at the belonging to a group" [Bourdieu 1986]. Coleman $(1988,1990)$ gave a new dimension to this concept by defining its function, where it is recognized as a variety of entities with two common elements: social structures of features and facilitation of individual actions within the structure. Coleman (1988) defined social capital as: "Social capital refers to the ability of individuals to work together into groups or organizations for a common purpose." In the early 1990s, this sociological concept was 
revived since it was adopted by political scientists, such as Putnam (1993) and Fukuyama (1995). Social capital is a sociological concept, which was adopted in the early 90 s by political scientists such as Putnam and Fukuyama. Putnam defined social capital as follows "the features of social life, such as networks, norms and trust that enable participants to act together more effectively to achieve shared objectives" [Putnam 1995]. However, social capital was defined in different ways by different researchers and can be considered as a set of networks, norms and values that help cooperation intra-groups and inter-groups to obtain mutual benefits. Given that social capital has a quality aspect; it is difficult to be measured. Indeed, the measurement of social capital refers to issues such as reliability, volunteer associations and charity institutions, membership organizations and clubs,... Many researchers have tried to find indicators of social capital: Coleman (1988), in his study on the contribution of social capital to human capital, Putnam $(1993,2000)$ in his studies on the relationship between social capital and economic performance and Knack and Keefer (1997) in their works on the links between social capital and economic outcomes. These authors used three types of indicators to measure social capital such as membership in local associations and networks, confidence indicators and adherence to standards and collective action indicators.

\section{The Concept of Entrepreneurship}

Entrepreneurship is intensively welded and dependent on innovation, with the aim of achieving a competitive advantage allowing a better positioning on the market. Its contribution can manifest on the one hand, in the governmental initiatives through public policies that promote and encourage the creation of new companies. And on the other hand through the organizations set up with the major objective of stimulating research and developing, and the deployment of all the resources necessary to create an environment within and favorable to the multiplication of opportunities. As a consequence, much research has been devoted to the theme of entrepreneurship as a key instrument to improve competitiveness worldwide, while promoting economic growth and increased employment opportunities.

The three major movements in the theory of entrepreneurship were revealed by: Schumpeter (1934) who defined entrepreneurship as innovation in the introduction of a new product; Baumol (1968) assumes that the valorization of entrepreneurship is developed by the advantages accorded to entrepreneurs, these advantages must be granted more productive innovation and not to snag an innovative rent. Finally, Kirzner (1973) confirmed that the event and the seizure of an opportunity presented a key factor for entrepreneurship.

Schumpeter (1934) defined innovation as the process by which new products and techniques are introduced into the economic system. Schumpeter's works also help to place entrepreneurship within the context of economic development. Indeed, for this author, the interest of entrepreneurship does not only lie in the development of innovation at the firms' level, but also from a macroeconomic perspective. Innovation appears as an engine of national economic development, it is a widely used indicator to know about a country's economic health.

By referring to the work of schumpeter, Baumol assumes that the agents optimize their entrepreneurial faculties, and this on the basis of the quality of the institutions that are economic, political and legal. This optimization would be directed either to the private sector through the creation of wealth, or to the public sector through the processes of wealth 
redistribution driven by political and legal procedures. Profitability remains the dominant factor in the decision-making of the entrepreneur; hence the institutions would be responsible for draining entrepreneurial activities towards the target and influential activities in economic growth.

Kirzner highlights the seizure of the opportunity, which presents the essentials for any entrepreneur. And by the fact that the productive ideas of profitable business opportunities were imperceptible. The realization of these ideas provides economic gain and better satisfaction for the market.

\section{Social Capital, Entrepreneurship and Economic Growth}

There are several mechanisms for social capital to positively affect economic growth. Knowles (2005) focuses on four mechanisms: The first refers to "the increase of mutually beneficial transactions" distinguished by several examples of cooperation based on trust and information. The second refers to "the resolution of collective action problems" which specifies that the share of the capital in the companies can give more solutions to the problems of collective action. "Reducing the cost of monitoring and transaction" is another mechanism for the functioning of social capital, mainly by trust. At last, social capital contributes to "the improvement of the flow of information" through groups or social networks.

Nevertheless, Greve and Al. (2006) indicated that "Social capital has four main effects: 1) Getting information; 2) transfer of knowledge, innovation, and diffusion of technology or practices; 3) combining complementary knowledge and helping solving problems; and 4) brokerage". They also presented other forms in which social capital provides greater productivity and fostering entrepreneurship: we can take the example of the use of social relations to encourage people to contribute to projects. A second form can be presented namely the use of the social capital of team members to enrich the knowledge of the team. The use of the social capital of members of these social networks and company sources can be consolidated and completed because a community of individuals provides more resources than a single individual.

Spellerberg (2001) stated that "access to Social capital can be considered to have three main functions: data processing, risk assessment and opportunities and evaluation of situations, people and organizations". These three functions are of crucial important in the society, because information is a key element of entrepreneurship and growth.

Thus, we can state that the social capital and the entrepreneurial dynamic are key factors of economic development. Social capital is an indispensable element for society in general and businesses in particular which facilitates the flow of information and the transfer of innovation. The entrepreneur's social capital plays an important role in facilitating access to information and resources. These resources are necessary so that they can develop and support their activities ${ }^{1}$. As for entrepreneurship, it affects economic development by increasing the level of revenue or reducing the level of unemployment. Social capital facilitates entrepreneur's access to information and resources that are cheaper than those offered by financial institutions. These resources are necessary for developing and supporting their activities.

1 Acs, Z. J., Audretsch, D. B., Lehmann, E. E., \& Licht, G. (2016). National systems of entrepreneurship. Small Business Economics, 46(4), 527-535. 


\section{Empirical Analysis}

Our research estimates the economic growth according to the social capital and entrepreneurial activity. Thus, our study focuses on the method analyzing static and dynamic panel data. Therefore, we conduct estimates using a model with individual effects. Thus, we realize estimations via a dynamic model by introducing the delayed endogenous variable as explanatory variables.

Based on the work of Mankiw et al. (1992), Demetriades and Law (2004), the objective of our empirical study is to add other determinants of economic growth to the equation of the growth model in order to address the relationship between social capital, entrepreneurship and economic growth. As a result, the model is presented as follows:

$Y_{i t}=\alpha_{i}+\beta_{1}$ Igdp_fit $+\beta_{2} I S K_{i t}+\beta_{3} I H K_{i t}+\beta_{4} I I N V_{i t}+\beta_{5} I F D_{i t}+\beta_{6} I I Q_{i t}+\beta_{7} \beta 7 I E_{i t}+\varepsilon_{i}$

The equation uses i to identify the country and t for time; with $\alpha_{i}$ is the individual specific effect; $\beta_{1}, \beta_{2}, \beta_{3}, \beta_{4}, \beta_{5}, \beta_{6}$ and $\beta_{7}$ are model parameters and $\varepsilon_{i}$ is the error term.

\section{Variables Presentation}

The variables used on the estimation are collected from panel data composed of 40 countries during a period ranged from 1990 to 2004 . The dependent variable is the real GDP per capita (Yit) and the independent variables are the logarithm of initial GDP per capita (Igdp_f), human capital (HK), the investment rate with respect to GDP (INV), financial development (FD), the institutional environment quality (IQ), social capital (SK) and entrepreneurship (E).

Human capital is measured by the average years of secondary schooling, physical capital is measured by the gross fixed capital formation, financial development is measured by the ratio of quasi-liquid liabilities to GDP. The institution environment quality is measured by civil freedom index published by the Freedom House on a scale from 1 (most free) to 7 (least free), social capital is measured by the confidence indices and associative density and finally the entrepreneurship indicator is measured by the number of patents filed by residents and nonresidents.

\section{Method of Estimation and Interpretation of Results}

The model structure, as it was shown above, leads us to make estimates on a heterogeneous panel model. Thus, we will adopt two econometric methods. Firstly, our model is estimated by the static panel data method, which allows studying the heterogeneity between individuals. The test of Hausman (1978) is a specification test of individual effects. It is used to discriminate the fixed and random effects. If the probability attached to the Hausman test statistic is less than $10 \%$, the fixed effect models (FEM) will be retained. If the probability is greater than $10 \%$, random effects models (REM) will be retained. Secondly, the followed econometric methods are the GMM (General Method of Moment) method in dynamic panel and a simultaneous equation model to resolve the issue of endogeneity of social capital.

\section{Direct Effects of Social Capital}

By estimating a sample of panel data, the first step is to check the homogeneous or heterogeneous data specification to verify if the theoretical model studied is perfectly identical to all countries or if there are specific characteristics for each country. 
The first step is to test the hypothesis of a perfectly homogeneous structure (constant and same slope).If the Fisher statistics associated with the total homogeneity test are above the Fisher statistical table, we reject the null hypothesis. In the second step, we test for the presence of individual effects by assuming that the $\beta i$ are constant for all the countries.

The results are presented in table 1.

Table 1: Direct effects of social capital on economic growth (static panel)

\begin{tabular}{lcc}
\hline Dependent Variable : & \multicolumn{2}{c}{ MEF } \\
Real GDP per capita $\left(Y_{\text {it }}\right)$ & $(1)$ & $(2)$ \\
\hline Igdp_f & -0.0888 & -0.1305 \\
& $(0.0332)^{* * *}$ & $(0.0374)^{* * *}$ \\
ISK & 0.0008 & 0.0008 \\
& $(0.0004)^{*}$ & $(0.0005)^{*}$ \\
IHK & - & 0.0247 \\
& & $(0.2002)$ \\
IINV & - & 0.0105 \\
& & $(0.0302)$ \\
IFD & - & 0.0075 \\
& & $(0.0197)$ \\
IIQ & - & -0.0169 \\
& & $(0.0280)$ \\
IE & - & 0.0125 \\
& & $(0.0056)^{* *}$ \\
Constant & 0.8541 & 1.1106 \\
& $(0.3017)^{* * *}$ & $(0.3225)^{* * *}$ \\
Observations & 200 & 200 \\
R2 & 0.5930 & 0.6411 \\
Hausman Test & 00057 & 0.0101 \\
\hline
\end{tabular}

Note: $*, * *, * * *$ denotes significance at $10 \%, 5 \%, 1 \%$.

The results obtained of the Fisher test allow us to reject the null hypothesis, so we should apply a model taking into account individual specificities. As mentioned in table 1 and for the first regression, the Hausman Statistics is about 10.35. Since the model uses two explanatory variables $(K=2)$, this statistic follows a chi-squared with two degrees of freedom and the threshold is 5.992. Therefore, we reject the null hypothesis of the absence of correlation between the individual effects and the explanatory variables. Therefore, we must use fixed effects models and retain the one within the estimator. Regression (1) shows that social capital has a positive and significant effect on economic growth. In addition, the initial GDP has a negative and significant coefficient confirming the conditional convergence hypothesis, as described in Mankiw, Romer and Weil (1992), in which the developing countries must grow faster than the developed ones.

In regression (2), we introduce other determinants of economic growth such as human capital (HK), investment rate (INV), financial development (FD), entrepreneurship (E) and the quality of institutions (IQ) measured by the index of civil liberty from 1 (countries with high degree of civil liberty) and 7 (countries with low degree of civil liberty). Therefore, we expect a negative coefficient when we use civil freedom index. The estimation of the Hausman statistics is about18.46. Model (2) contains seven explanatory variables ( $K=7)$, this statistic 
follows a chi-squared with seven degrees of freedom with a threshold equals to14.067. We conclude that the estimates made, will be those of individual fixed effects models. Social capital has retained its statistical significance compared to the previous regression. Entrepreneurship measured by the number of patents filed by residents and non-residents has a positive and significant impact on economic growth. Feki and Chtourou (2014) in 45 countries find a negative relationship between entrepreneurship and growth for the period 1990-2004 when entrepreneurship is measured through self-employment. Salgado-Banda (2007) used the number of patent and self-employment to measure entrepreneurship. He concluded that self-employment is negatively correlated with the real GDP per capita in 22 OECD countries over the 1980-1995 periods, while innovation measured by the number of patents is positively correlated with the economic growth.

After making our estimations using fixed effects, we will proceed in a second step, with the GMM estimators of Arellano-Bond (1991). Each of these techniques has its own advantages. Individual effects assume the existence of identical coefficients for all individuals and specific constants. Hence, the estimate of the economic relationship through this type of modeling is assumed to different for every individual level introduced in the model are provided in the absence of endogeneity problem.

GMM analysis introduces fixed effects by country and produces consistent estimators in the presence of the lagged dependent variable. In addition, the introduction of the delayed dependent variable in the analysis, the GMM method takes all the requirements of endogeneity. This explains the exponential use of dynamic panel data in recent studies on growth.

Dynamic panel data models use the lags of the dependent variable as explanatory variables, the introduction of the lags becomes crucial to control for the dynamics of the process. The dynamic panel has two variants of the GMM estimator: the first is the "GMM difference" estimator and the second is the "GMM system" estimator. The efficiency of the GMM estimate is based on the validity of two tests: the over-identification test Sargan / Hansen, who tests the validity of the lagged variables as instruments, and testing Arellano-Bond for autocorrelation where the null hypothesis is the absence of autocorrelation of the first order errors in the equation level.

Starting from equation [1], the estimates performed using the system GMM dynamic via the introduction of the delayed endogenous variable as an explanatory variable. This is shown in equation [2]:

$Y_{i t}=\alpha_{i}+\beta_{1} Y_{i t} 1+\beta_{2} I g d p \_f_{i t}+\beta_{3} I S K_{i t}+\beta_{4} I H K_{i t}+\beta_{5} I I N V_{i t}+\beta_{6} I F D_{i t}+\beta_{7} I I Q_{i t}+\beta_{8} I E_{i t}+\varepsilon_{i t}[2]$

The estimated results are described in Table 2 . 
Table 2: Direct effects of social capital on economic growth (dynamic panel)

\begin{tabular}{lcc}
\hline Dependent Variable : & \multicolumn{2}{c}{ System GMM } \\
Real GDP per capita $\left(Y_{\text {it }}\right)$ & $(1)$ & $(2)$ \\
\hline$Y_{\text {it_1 }}$ & -0.0980 & -0.0497 \\
Igdp_f & $(0.1404)$ & $(0.1451)$ \\
& 0.0764 & 0.0246 \\
ISK & $(0.0473)$ & $(0.0342)$ \\
& 0.0011 & 0.0014 \\
IHK & $(0.0007)^{*}$ & $(0.0008)^{*}$ \\
& - & 0.0549 \\
IINV & & $(0.0248)^{* *}$ \\
& - & 0.0325 \\
IFD & - & $(0.0382)$ \\
& & -0.0250 \\
IIQ & - & $(0.0354)$ \\
& & -0.0060 \\
IE & - & $(0.0446)$ \\
& & 0.0022 \\
Constant & & $(0.0092)$ \\
& -0.6399 & -0.2295 \\
Observations & $(0.4254)$ & $(0.3035)$ \\
Hansen Test & 160 & 160 \\
AR(2) & 0.622 & 0.274 \\
Note: $* * * * *$ & 0.633 \\
\end{tabular}

Note: $*, * *, * *$ denotes significance at $10 \%, 5 \%, 1 \%$.

The regressions results of both tests are presented in line with our expectations. Indeed, the statistics are favorable and the null hypothesis of the validity of the lagged variables as instruments is not rejected. The over-identification Hansen test does not reject the validity of instrumental variables and the Arellano and Bond test does not reject the null hypothesis of no autocorrelation of second order. The results of the various regressions with the system of GMM dynamic panel method confirm the significant positive effect of social capital on economic growth. The results also show that there is a positive and significant relationship between social capital and human capital. However, other variables are surprisingly not considered significant, despite the positive sign. These results can be explained by the presence of the initial level of income as an explanatory variable.

The result show that social capital has two effects on economic growth: a direct effect caused by the fact that social capital can be seen as a determinant of economic growth, such as the physical or human capital (Coleman, 1988). A second indirect effect transmitted to economic growth through the other mentioned variables: the quality of institutions, education, investment, financial development and entrepreneurship.

To distinguish between the direct and indirect effects of social capital on economic growth, we use a simultaneous equation model. 


\section{Indirect Effects of the Transmission Channels on Social Capital}

In order to test empirically the effect of social capital on each transmission channel, we performed a series of regressions presented in equation [3], then we used a simultaneous equation model (equation [4]), which also overcomes the problem of endogeneity. The results of the estimations are presented in the table below:

$$
\left\{\begin{array}{l}
I H K_{i t}=\alpha_{i}+\beta_{1} \operatorname{lgdp} \_f_{i t}+\beta_{2} I S K_{i t}+\varepsilon_{i t} \\
I I N V_{i t}=\alpha_{i}+\beta_{1} \operatorname{lgdp} \_f_{i t}+\beta_{2} I S K_{i t}+\varepsilon_{i t} \\
I F D_{i t}=\alpha_{i}+\beta_{1} \operatorname{Igdp} f_{i t}+\beta_{2} I S K_{i t}+\varepsilon_{i t} \\
I I Q_{i t}=\alpha_{i}+\beta_{1} \operatorname{Igdp} f_{i t}+\beta_{2} I S K_{i t}+\varepsilon_{i t} \\
I E_{i t}=\alpha_{i}+\beta_{1} \operatorname{lgdp} \_f_{i t}+\beta_{2} I S K_{i t}+\varepsilon_{i t}
\end{array}\right.
$$

The estimation of these equations takes into consideration the indirect effects of social capital on economic growth.

Table 3Indirect effects of social capital on economic growth (estimated by the simultaneous equations method)

\begin{tabular}{|c|c|c|c|c|c|c|}
\hline \multirow[t]{2}{*}{ Dependent Variable } & IHK & IINV & IFD & $\| \mathrm{Q}$ & IE & \multirow{2}{*}{$\begin{array}{c}Y_{\text {it }} \\
{[4]}\end{array}$} \\
\hline & \multicolumn{4}{|c|}{ [3] } & & \\
\hline lgdp_f & $\begin{array}{c}0.3348 \\
(0.1854)^{*}\end{array}$ & $\begin{array}{c}0.3557 \\
(0.1217)^{* *} \\
*\end{array}$ & $\begin{array}{c}0.5492 \\
(0.1892)^{* *} \\
*\end{array}$ & $\begin{array}{c}0.1263 \\
(0.1256 \\
)\end{array}$ & $\begin{array}{c}0.9211 \\
(0.6581 \\
)\end{array}$ & $\begin{array}{c}-0.2992 \\
(0.0367)^{* *} \\
*\end{array}$ \\
\hline ISK & $\begin{array}{c}0.0047 \\
(0.0017)^{* *} \\
*\end{array}$ & $\begin{array}{c}0.0040 \\
(0.0011)^{* *} \\
*\end{array}$ & $\begin{array}{l}-0.0003 \\
(0.0017)\end{array}$ & $\begin{array}{c}-0.0004 \\
(0.0011 \\
)\end{array}$ & $\begin{array}{c}0.0037 \\
(0.0062 \\
)\end{array}$ & $\begin{array}{c}0.0007 \\
(0.0003)^{* *}\end{array}$ \\
\hline IHK & & & & & & $\begin{array}{c}0.0085 \\
(0.0152)\end{array}$ \\
\hline IINV & & & & & & $\begin{array}{c}0.0451 \\
(0.0230)^{* *}\end{array}$ \\
\hline IFD & & & & & & $\begin{array}{c}0.0091 \\
(0.0150)\end{array}$ \\
\hline IIQ & & & & & & $\begin{array}{c}0.0193 \\
(0.0223)\end{array}$ \\
\hline IE & & & & & & $\begin{array}{c}0.0103 \\
(0.0042)^{* *}\end{array}$ \\
\hline Constant & $\begin{array}{l}-1.7655 \\
(1.5664)\end{array}$ & $\begin{array}{c}0.4208 \\
(1.0280)\end{array}$ & $\begin{array}{l}-1.8263 \\
(1.5985)\end{array}$ & $\begin{array}{c}0.5825 \\
(1.0612 \\
)\end{array}$ & $\begin{array}{c}-2.5769 \\
(5.5591 \\
)\end{array}$ & $\begin{array}{c}2.2577 \\
(0.3040)^{* *} \\
*\end{array}$ \\
\hline Observations & 200 & 200 & 200 & 200 & 200 & 200 \\
\hline
\end{tabular}

Note: $*, * *, * * *$ denotes significance at $10 \%, 5 \%, 1 \%$.

The estimated equations reported in equation [4] show that investment and entrepreneurship are positive and significant. Table (3) also reveals that social capital is 
positively and significantly correlated with economic growth. In other words, after taking into consideration the indirect effects of social capital on economic growth through the transmission channels, we find that social capital is significant at a $5 \%$ level of confidence. In addition, entrepreneurship measured by the number of patents filed by residents and nonresidents has a positive and significant impact on economic growth. Entrepreneurship is also significant at a $5 \%$ level of confidence. This result is consistent with the theoretical and empirical literature presented above.

In other studies on the link between social capital and growth, Knack and Keefer (1997) found that a one standard deviation increase in the prevailing level of trust is associated with a rise in economic growth of more than one half of a standard deviation. According to Zak and Knack (2001), the economic growth rises by approximately 1\% on average after a 15 percentage increase in trust. Such result was found to be robust in Beugelsdijk, de Groot and van Schaik, (2004) using the extreme bound method.

However, to our knowledge, all these contributions did not explicitly study the transmission channels of social capital to economic growth. Therefore, the aim of this work is to focus on these aspects by studying the relative contribution of each of the determinants of economic performance.

\section{Conclusion}

The purpose of this work is to empirically study the direct and indirect effects of social capital on the GDP growth rate per head for a sample of developed and developing countries. For this purpose, we use the method of panel data to solve problems of endogeneity of the independent variable (the social capital).

In this context, we have evaluated the relationship between social capital, entrepreneurship and economic growth. The prospect of social capital implies that the social network links provide individuals and organizations with access to knowledge and other resources. Social networks of a new business are the most important resources. Besides, social contacts of the entrepreneur are often the key strategic elements that are able to improve the development of new businesses.

This paper shows that the social capital and economic growth are significantly and positively correlated; in addition, it indicates that a high level of social capital has an indirect effect on economic growth through its effect on entrepreneurial activity. Thus, this research gives both theoretical and empirical answers to the effect of adequate social capital on the strengthening of entrepreneurial activity which could have positive effects on investment and economic growth.

These results verify the review of the literature cited above, essentially the work of Spellerberg (2001) and Greve \& Al. (2006).

\section{References}

Arellano, M. \& Bover, O. (1995). Another look at the instrumental-variable estimation of error-components models. Journal of Econometrics, 68(1), 29-51.

Arellano, M. \& Bond, S. (1991). Some Tests of Specification for Panel Data: Monte Carlo Evidence and an Application to Employment Equations. Review of Economic Studies, $58(2), 277-297$.

Audretsch, D. B. (2007). Entrepreneurship capital and economic growth. Oxford Review of Economic Policy, 23(1), 63-78. 
Banfield, E.G. (1958). The Moral Basis of a Backward Society, New York, Free Press.

Baumol, W. J. (1968). Entrepreneurship in Economic Theory. American Economic Review, 58(2), 64-71.

Baumol, W. J. (1990). Entrepreneurship, Productive, Unproductive an Destructive. Journal of Political Economy, 98(5), 893-921.

Beugelsdijk, S. Groot, D. H. \& Schaik, V. A. (2004). Trust and economic growth: a robustness analysis. Oxford Economic Papers, 56(1), 118-134.

Beugelsdijk, S. \& Schaik, V. T. (2005). Social capital and regional economic growth. European Journal of Political Economy, 21(2), 301-324.

Blundell, R. \& Bond, S. (1998). Initial conditions and moment restrictions in dynamic panel data models. Journal of Econometrics, 87(1), 115-143.

Bourdieu, P. (1980). Le capital social. Actes de la Recherche en Sciences Sociales, (31), 2-3.

Bourdieu, P. (1986). The Forms of Capital. dans J.E. Richardson (dir. pub.), Handbook of Theory of Research for the Sociology of Education, Greenwood Press, New York, pp. 241-258.

Coleman, J.S. (1988). Social capital in the creation of human capital. American journal of sociology, (94), 95-120.

Coleman, J.S. (1990). Foundations of Social Theory. Cambridge, MA, Belknap Press of Harvard University Press. Chapter 1: Metatheory: Explanation in Social Science, pp. 1-23.

Demetriades, P. \& Law, S. (2004). Finance, Institutions and Economic Growth. University of Leicester Discussion Papers in Economics 04/5.

Feki, C. \& Chtourou, N. (2014). Entrepreneuriat et croissance économique : effet du capital social. International Journal of Innovation and Applied Studies, 6(3), 677-690.

Fukuyama, F. (1995). Trust: the social values and the creation of prosperity ", New York: The free press.

Boulila, G. Bousrih, L. \& Trabelsi, M. (2008). Social capital and economic growth: empirical investigations on the transmission channels. International Economic Journal, 22:3, 399 - 417, DOI: 10.1080/10168730802287994.

Greve, A. Benassi, M. \& Dag, Sti, A. (2006). Exploring the Contributions of Human and Social Capital to Productivity. Paper presented at SUNBELT XXVI, Vancouver, BC, pp. 25-30.

Hanifan, L. J. (1916). The rural school community center. Annals of the American Academy of Political and Social Science, 67(1), 130-138.

Hausman, J. (1978). Specification Tests in Econometrics. Econometrica, 46(6), 1251-1271.

Homans, G. (1961). Social Behavior: Its Elementary Forms. New York: Harcourt Brace Jovanovich, pp. 13.

Jacobs, J. (1961). The Death and Life of Great American Cities. New York, Random House.

Kirzner, I. M. (1973). Competition and Entrepreneurship. Chicago and London: University of Chicago Press.

Knack, S. \& Keefer, P. (1997). Does Social Capital Have an Economic Payoff? A Cross-Country Investigation. Quarterly Journal of Economics, 112(4), 1251-1288.

Knowles, S. (2005). The Future of Social Capital in Development Economics Research. A paper prepared for the WIDER Jubilee Conference: Thinking Ahead: The Future of Development Economics. Helsinki, pp. 17-18.

Koo, J. \& Kim, T. E. (2009). When R\&D matters for regional growth: A tripod approach. Papers in Regional Science, 88(4), 825-840. 
Loury, G. (1977). A Dynamic Theory of Racial Income Differences. in Wallace, P.A., Le Mund,E., (eds.), Women, Minorities, and Employment Discrimination. Lexington, MA, Lexington Books.

Mankiw, G. Romer, D. \& Weil, D. (1992). A contribution to the empirics of economic Growth. Quarterly Journal of Economics, 107(2), 407-437.

ljaz, M. Yasin, G. \& Zafar, M. J. (2012). Cultural Factors Effecting Entrepreneurial Behaviour Among Entrepreneurs. Case Study of Multan, Pakistan. International Journal of Asian Social Science, 2(6), 908-917.

Bahmani-Oskooee, M. (2008). Social Capital and Entrepreneurship in a Regional Context: The Case of Spanish Regions", from book Entrepreneurship and business: A regional perspective (pp.101-111)

Putnam, R. (1995). Bowling Alone: America's Declining Social Capital. Journal of Democracy. 6(1), 65-78.

Putnam, R. (2000). Bowling Alone: The Collapse and Revival of American Community. New York, Simon and Schuster.

Putnam, R. Leonardi, R. \& Nanetti, R. Y. (1993). Making Democracy Work: Civic Tradition in Modern Italy. Princeton, Princeton University Press.

Salgado-Banda, H. (2007). Entrepreneurship and Economic Growth: An Empirical Analysis. Journal of Developmental Entrepreneurship, 12(1), 3-29.

Sargan, J. D. (1958). The estimation of economic relationships using instrumental variables. Econometrica, 26(3), 393-415.

Schumpeter, J. (1934). The theory of economic development. Cambridge Mass., US: Harvard University Press.

Spellerberg, A. (2001). Framework for the Measurement of Social Capital in New Zealand. Statistics New Zealand, Wellington, New Zealand.

Vázquez-Rozas, E. Gomes, S. \& Vieira, E. (2010). Entrepreneurship and economic growth in Spanish and Portuguese Regions. Regional and Sectoral Economics Studies, 10(2), 109126.

Zak, P. J. \& Knack, S. (2001). Trust and Growth. Economic Journal, 111(470), 295-321. 